\title{
Evaluating urban agriculture program effectiveness using CIPP model: a review
}

\author{
Munifah Siti Amira Yusuf $^{1}$, Norsida Man $^{1 *}$, Nur Bahiah Mohamed Haris ${ }^{1}$, Ismi Arif Ismail ${ }^{2}$, \\ and Amar Maruf ${ }^{3}$ \\ ${ }^{1}$ Department of Agriculture Technology, Faculty of Agriculture, Universiti Putra Malaysia (UPM), \\ Serdang, 43400, Selangor, Malaysia \\ ${ }^{2}$ Department of Professional Development and Continuing Education, Faculty of Educational Studies, \\ Universiti Putra Malaysia (UPM), Serdang, 43400, Selangor, Malaysia \\ ${ }^{3}$ Department of Environmental Science, Faculty of Forestry and Environmental Science, Universitas \\ Halu Oleo Kendari, Indonesia
}

\begin{abstract}
The art of planting, preparing, and distributing food around urban areas is known as urban agriculture, farming, or gardening. Individuals and organizations generally work in urban agriculture for general purposes: 1) enhancing their own health and economic circumstances; 2) improving their communities' access to nutritious food; 3 ) enhancing their community wellbeing; and 4) developing a community and ecosystem. The Urban Agriculture Program (UAP) has been set up by the Department of Agriculture (DOA) Malaysia since 2014 to facilitate and transfer information regarding urban farming practices to the community. However, the program was less effective and had a low success rate due to the local community's minimal participation, slow development, and sustainability of the agriculture community gardens. This article primarily examines the UAP implementation based on the four components of the CIPP Evaluation Model: Context, Input, Process, and Product. The UAP is a sustainable development tool that can provide food or related services within or on the edges of urban areas. Malaysia addresses food security by providing urban dwellers with adequate nutritious, safe, acceptable, and cost-effective food. Therefore, the study is relevant as achieving food security and nutrition that has been set in the urban agriculture program outcome by 2025 .
\end{abstract}

\section{Introduction}

Urban Agriculture (UA), in particular, can significantly contribute to greening cities and enhancing urban climate, as well as promoting the reuse of urban organic waste and lowering the urban energy footprint [1]. Generally, urban agriculture serves urban society as part of different functions, including production, energy conservation, waste management, biodiversity, control of microclimate, urban greening, recovery in the economy, socialization in communities, human health, cultural heritage, and education [2]. The importance of urban agriculture practices has been addressing many times by most countries. Various studies have

*Corresponding author: norsida@upm.edu.my 
shown and recognized that food security and nutrition can be derived from urban agriculture to provide sufficient quantities of food, appropriate nutrition, cost-effective food supplies, and reduction in food bills [3].

These facts stresses the need for Malaysian urban authorities to give city dwellers more acceptable recognition and contribution, and enable them to extend their use of urban agriculture. The Malaysian Government has fully supported this effort, having recognized the importance of UA by the formation of Malaysia's UA Division in 2010. The formation of this division primarily aims to promote the agriculture of the urban community for its wellbeing. This program is intrinsically a campaign program, was initiated in 1974 which known as Green Book Project and Green Earth Campaign in 2006.

\section{Urban agriculture (UA) in Malaysia}

Malaysian Government has recognized the importance of the UA and has led the development of the program under the Department of Agriculture Malaysia in 2010. The critical functions of this division are basically to (a) provide advisory services, technical consulting, and training in acceptable farming practices in urban areas ; (b) apply and encourage applicable farming methods in urban areas ; and (c) prepare, organize, and track urban farmer programs and activities [4].

Under this urban agriculture division, several campaign programs have been implemented mainly to allow urban residents to participate in agricultural activities for their wellbeing. The program started from the two earlier campaigns, Green Book Project (Rancangan Buku Hijau), in 1974 before switching to the Green Earth Campaign (Kempen Bumi Hijau) in 2006. The goals of both initiatives were to : (a) encourage people to grow their vegetables for daily consumption, and (b) encourage people to produce their food to mitigate the effects of inflation and rising food prices [5].

In addition, the Department of Agriculture had launched the Urban Agriculture Program (UAP), in 2014 which aims to allow urban residents to farm for their food and as a source of income. From September 2014 to December 2016, UAP had 63,129 participants across the country, with an RM10 million budget allocated to 2,715 project locations. UAP is carried out under the direction of the Department of Agriculture, with the cooperation and participation of several related States and Federal Departments and Agencies, including MPSJ, the urban and rural development department (JPBD), MARDI, and district or state municipalities.

The progress of urban agricultural development projects so far from 2014 until 2020 has shown that more than 150000 participants were recorded as participating in urban agriculture development in Malaysia [5]. The participant consists of four main groups known as individual housing, community housing, schools, and institutions as shown in Table 1. Despite the number of participants that have been recorded on programs organized by the Department of Agriculture (DOA), it is assumed that a more significant number of urban residents are involved in urban agriculture, particularly those who do it informally [4]. 
Table 1. Progress of urban agricultural development projects 2014-2020

\begin{tabular}{|l|c|c|c|c|c|}
\hline \multirow{2}{*}{ State } & \multicolumn{5}{|c|}{ Number of participants in 2014-2020 } \\
\cline { 2 - 6 } & $\begin{array}{c}\text { Housing } \\
\text { area } \\
\text { (individual) }\end{array}$ & $\begin{array}{c}\text { Housing area } \\
\text { (community) }\end{array}$ & School & Institution/private & Total \\
\hline Perlis & 1817 & 1285 & 2178 & 782 & 6062 \\
\hline Kedah & 1800 & 1226 & 1460 & 883 & 5369 \\
\hline Pulau Pinang & 1914 & 1685 & 2299 & 983 & 6881 \\
\hline Perak & 5435 & 3677 & 7763 & 3830 & 20705 \\
\hline Selangor & 2112 & 12759 & 3728 & 1994 & 20593 \\
\hline Negeri Sembilan & 1574 & 1534 & 1879 & 563 & 5550 \\
\hline Melaka & 3606 & 1958 & 3047 & 1980 & 10591 \\
\hline Johor & 4858 & 4557 & 6877 & 2514 & 18806 \\
\hline Pahang & 3899 & 1600 & 4560 & 1055 & 11114 \\
\hline Terengganu & 4198 & 1306 & 4875 & 1986 & 12365 \\
\hline Kelantan & 3093 & 962 & 3137 & 1561 & 8753 \\
\hline W.P Putrajaya & 1035 & 883 & 1368 & 839 & 4125 \\
\hline W.P. Kuala Lumpur & 1764 & 5301 & 2313 & 1245 & 10623 \\
\hline W.P Labuan & 2223 & 1113 & 1448 & 977 & 5761 \\
\hline Sabah & 3545 & 927 & 1680 & 560 & 6712 \\
\hline Sarawak & 2382 & 111 & 1898 & 926 & 5317 \\
\hline Total & 45255 & 40884 & 50510 & 22678 & 159,327 \\
\hline Source: Departmen
\end{tabular}

Source: Department of Agriculture Malaysia (2020)

However, the effort was less effective due to the report stated by [6]. The success rate of the program results is said to be still low without any involvement of the local community, development, and sustainability of the agriculture community gardens. It may be due to a weakness in the process of conducting the activities.

The finding indicates a need to understand factors contributing to the effectiveness of the UA program. A reasonable approach to tackle this issue could be through establishing assessment and evaluation model so that the program could be improved later. Briefly, this study highlights several problems that may affect the effectiveness of the UA program. The specific issues on this study are listed as follows:

\section{Issue 1}

By referring to the guidebook for module development by [7], the suitability of content evaluation on the first group of participants should be monitored every four to five years. However, limited studies were conducted to evaluate the effectiveness of the Urban Agriculture Program (UAP) implementation by the DoA on enhancing participants' food security and nutrition particularly in Malaysia.

\section{Issue 2}

Previous studies on urban agriculture only focus either on urban agriculture practices, students' intention to participate in UA program, factors influencing, perception of community, the implication for extension workers, or the role of knowledge among farmers $[8,9,10,11]$. However, limited evaluation studies on formative and summative way [through CIPP (Context-Input-Process-Product) Evaluation Model] of the implementation of the UAP were carried out. 


\section{Issue 3}

The main issues and problems have been recognized during the implementation of urban farming community programs: the participants' commitment, lack of knowledge, area problems, disease and pest attacks, disaster problems and high maintenance costs [12]. Previous researches only considered the program's with certain variables and limited research has been done in evaluating the program in dimensions of Context, Input, and Process based on perceptions of participants and DoA. Besides, the proposed CIPP model of evaluation has less been used on agricultural extension programs, specifically on the UA program.

Despite the findings of few relevant studies, whether directly or indirectly has been conducted and discussed in the background of the study for urban agriculture practices in Malaysia, studies that directly and comprehensively cover the assessment system conducted, particularly on the implementation of UA program are still vague and thus require a more thorough and comprehensive evaluation. Thus, from this concept paper, the researcher intends to evaluate the Urban Agriculture Program by applying CIPP evaluation model to ensure the effectiveness and success of the program.

\section{CIPP evaluation model}

This study will employ CIPP Evaluation in evaluating the effectivess of the Urban Agriculture Program implemented by DoA Malaysia. Stuftlebeam [13] developed an assessment model, generally known as the CIPP model, to provide valuable knowledge to decision-makers. In the 1980s, Stufflebeam upgraded the model. In essence, the CIPP model is intended to answer: 1) the targets should be set; 2) the methods are to be applied; 3) how those procedures are to function; and 4) how the objectives are to be achieved in terms of effectiveness. Following these questions, the assessment of four forms can be carried out (Figure 1).

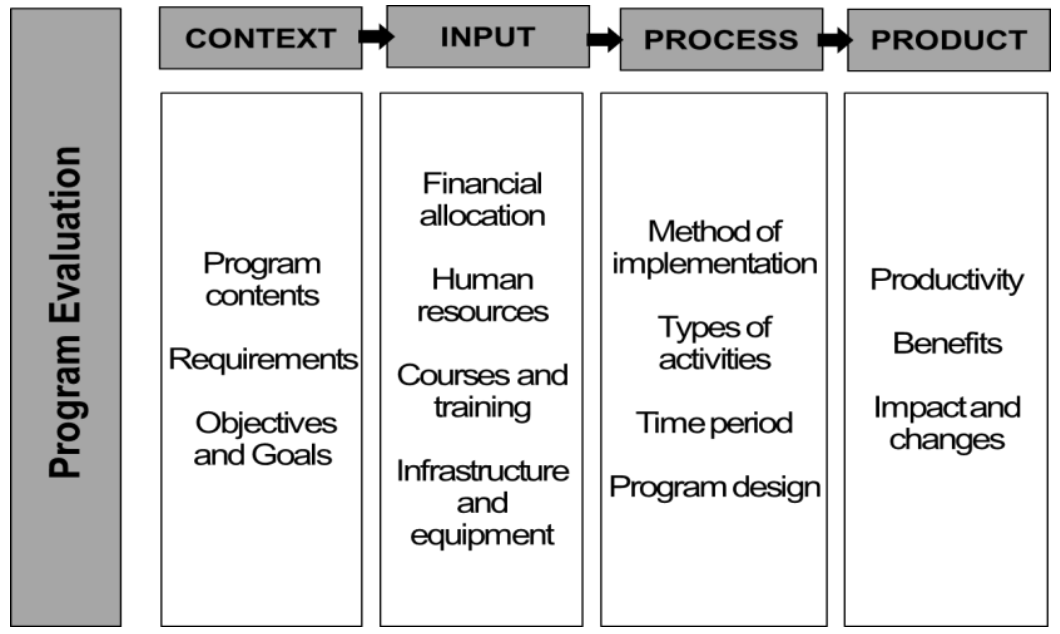

Fig. 1. CIPP evaluation model

The CIPP model can be used for both type of assessment that is summative and the formative evaluation. In this model, the overall perspective for individual aspects is evaluated from every angle by context, input, process, and output. Based on the four levels in this Stufflebeam assessment model, policymakers, program implementers, and anyone relevant 
can carry out assessments to develop a program, to follow the strength of a given program or service, to see how effective it is, and to contribute to knowledge [14].

Although the project is already underway, it helps in shaping the progress of the CIPP. The CIPP work steps are more versatile and easier to follow, and during the project, different cases or scenarios can be examined. Besides, when the course has to be changed, the evaluator must inspect any weak dimensions for the initial term to be repaired [15]. This ability to conduct evaluations varies, either before, during, or after the program's execution. The emphasis is on the collection of information for decision-making purposes. For the program itself or as a guide to other programs, the information obtained is beneficial.

There are several evaluation studies conducted using CIPP Model. Gurning [16] implemented a study on the performance of Agribusiness Microfinance Institutions (MFIA) using the Context, Input, Process, and Product (CIPP) approach in the district of Gunungkidul, Yogyakarta, Indonesia revealed that indicators in CIPP Models produced results indicating the performance of the program met the best criteria. Man [17] also supported such a result when conducting a study on evaluating the Women Economic Development (WEDA) program in Sarawak. This study found that the participants showed some noticeable positive changes in terms of knowledge and skills, confidence level, business size, and attitude towards company success. Furthermore, in an observation-based study by [18], the findings have shown that the evaluation model of CIPP used to carry out the study helps ensure that essential elements influencing project implementation are not overlooked at various phases of creation and execution. Per this study, in accordance with this study, the researcher will use this model to assess the extent of implementing the DoA's UA program.

\section{Agricultural extension program evaluation}

Agricultural extension services are available all over the world. Agricultural extension programs have been primarily responsible for faciliting learning and extending new knowledge and technology in informal education to lift agricultural productivity, farmers, and community income. A variety of approaches can measure the effectiveness of a program. An evaluation is to evaluate the short and medium-term outcomes of the agricultural program. [19] reports that an evaluation of agricultural extension programs, to decide it, enhance its performances or decide on plans, involves structured information, or knowledge regarding program activities, features and results. According to [20], it is not straightforward to assess the effectiveness of extension programs and services as there are various points of view and conclusions drawn from individuals reviewed, leading to different findings [21].

Evaluating is an art as well as a science. The art of evaluation entails determining objectives and target audiences, developing appropriate designs, and interpreting data about a program or policy. The science of evaluation entails collecting and analyzing evidence about outcomes and impacts systematically [22]. Some studies have considered the dependence of science and combining agriculture extensions and the positive relationship between them and farm productivity [23]. Another group focused on the impact assessment of extension programs by comparing farmers in contact with extension agents without contact [24]. Several research studies have assessed extent performance measurement by measuring changes or interactions between farmers and extension agents [25].

The overall objective of most countries is to increase food and nutrition security by increasing agricultural productivity and profitability and is to increase agricultural expansion. Extension services are nevertheless organized in many respects due to different purposes, aims, context, and external support types and levels. Different countries have established a different types of extending systems. Government policies affect farming by incentives and prices and subsequently influence the impact on extension. If research efforts are ineffective, the extension will not pay high, as there is no information or technology to be transmitted. 
Due to the shrinking public budgets and the need to fund a wide range of development initiatives, policymakers and funding agencies are increasingly requesting information on how extension program money is spent and the programs' outcomes. Consequently, program evaluation is becoming increasingly crucial.

Urban agriculture has always been associated with agricultural extension service as it is executed by Urban Agriculture division under the Department of Agriculture Malaysia. The function of Department of Agriculture is responsible for any agriculture services and to implement the agricultural policies outlined by the government. One of the main objectives of DOA is provide agricultural extension and development services through technology transfer based on Good Agricultural Practices (GAP) along the value chain to increase production and income as well as to ensure the production of adequate, quality and safe food. In addition, the Urban Agriculture division is ultimately to foster the urban community's practice of agriculture for their well-being. It is known as campaign program by nature which was derived from two earlier campaign program known as the Green Book Project in 1974 and the Green Earth Campaign in 2006. This urban agriculture program has been conducted for about more than 10 years which the suitability of the program content should be monitored and evaluated every four to five years. Hence, this paper describes the need for evaluation and address issues related to improving the quality of measuring impacts of agricultural extension programs focusing on urban agriculture program using effective methods.

\section{Food security and urbanization in Malaysia}

Food security refers to ensuring that everyone in a population has enough food to fulfill their nutritional requirements. There are four key factors to define food safety: availability (for use), physical and economic access (by purchase or manufacture of food), food uses (for human nutrient use), and food supply stability (concerning sudden shocks and cycles). A population has a high level of food security when it can obtain enough food at reasonable prices to meet its consumption and nutritional needs. According to [3], food security can be derived from urban agriculture because it provides adequate quantities of food, appropriate nutrition, cost-effective food supplies, and reduced food bills. Urban agriculture has become more critical as urban poverty and population in developing areas are increasing. Malaysian urban agriculture is one tool for long-term growth to provide food and related services within or on the outskirts of cities.

Furthermore, rapid urbanization and climate change have been at the root of the problem. Growing cities have threatened to strain existing supply chains while changing weather patterns have already reduced average yields for the world's top ten crops by $1 \%$. The population is growing, climate change is occurring, and consumers want more. Because a perfect storm is brewing, this will have an impact on how it grows. There are numerous challenges to growing food at home, particularly for people living in cities, because gardens are often small or non-existent, and public spaces are rarely available for food production.

In connection with food security and urban development in Malaysia, it has been recognized that urban farming is in line with the direction of the transformation plan that aims at strengthening the communities' food safety and nutrition by 2025 . Many studies have been carried out to provide an overview of urban agriculture as a great potential among Malaysian city dwellers. However, only a few studies have been conducted to assess the efficacy of the Department of Agriculture's Urban Agriculture program in improving participants' food security and nutrition in Malaysia.

Lastly, in accordance to the evaluation model it will be used to assess the effectiveness of the CIPP program implementation by the DOA on enhancing participants food security and nutrition in Malaysia. This study is very significant for to assess the current effect of the 
program on the participants and to recommend measures for its continuous quality improvement.

\section{Conclusion}

In line with the significance of an evaluation for agricultural extension programs and the importance of urban agriculture in Malaysia, this study aimed to evaluate the program for urban agriculture based on the CIPP Model, and develop and apply an appropriate and realistic UAP model to assess the efficiency of agricultural programs in extension units. Within this framework, a study will be carried out to ensure the implementation of the program is aligned with the direction of the transformation plan based on the empowerment of the community in terms of enhancing their food security and nutrition by 2025 . To summarize, the CIPP assessment model can be used in any program currently being implemented or has previously been implemented for quality improvement. This research is critical in determining the program's current impact on participants and recommending steps to ensure high quality. As a result, this study will identify the gap between the actual situation and the planning expectation by utilizing elements from the (CIPP) evaluation framework. This method will enhance the program's efficiency being assessed, namely the UA program by the DOA.

Acknowledgement. Munifah Siti Amira Yusuf, Norsida Man, Nur Bahiah Mohamed Haris, Ismi Arif Ismail and Amar Maruf wish to thank and acknowledge the Faculty of Agriculture and Universiti Putra Malaysia (UPM) for great technical and financial support. No potential conflict of interest was reported by the authors.

\section{References}

1. Dubbeling, M., \& De Zeeuw, H. Urban Agriculture and Climate Change Adaptation: Ensuring Food Security Through Adaptation. In Resilient Cities (pp. 441-449). Springer Netherlands (2011).

2. Lovell, S. T. Multifunctional urban agriculture for sustainable land use planning in the United States. Sustainability, 2, 8: 2499-2522 (2010)

3. Rezai, G., M.N. Shamsudin, and Z. Mohamed. Urban Agriculture: A Way Forward to Food and Nutrition Security in Malaysia. Procedia-Social and Behavioral Sciences 216: 39-45 (2016)

4. Mad Nasir Shamsuddin, Ahmad Hanis Izani Abdul Hadi, Alias Radam and Yahya Awang. Policy and Socio-Economic Impacts of Urban Agriculture in Malaysia. Book Chapter of Urban Farming in Malaysia, Improving Food Security While Greening the Environment (pp. 55-70). Serdang Selangor Malaysia: University Putra Malaysia Press (2017)

5. Department of Agriculture Malaysia. Progress of Urban Agricultural Development Projects (2014-2020).

6. Schutte, D.W. The Basic Needs Theory for Community Development. Unitec Institute of Technology. Auckland, New Zealand. Unitec Institute of Technology. Auckland, New Zealand (2015)

7. UTHM. Garis Panduan Pembangunan Modul Pengajaran dan Pembelajaran Universiti Tun Hussein Onn Malaysia. (S. Sarif, Ed.) (Pertama). Parit Raja, Batu Pahat: Pejabat Penerbit, Universiti Tun Hussein Onn Malaysia (2011)

8. Tiraieyari, N., Hamzah, A., Krauss, S. E., \& Ismail, I. A. International Journal of Academic Research in Business and Social Sciences, 7, 8 : 659-664 (2017)

9. Tiraieyari, N., \& Krauss, S. E. Agriculture and Human Values, 35, 3 : 637-650 (2018) 
10. Tiraieyari, N., \& Uli, J. Journal of American Science, 7, 8: 179-182 (2011)

11. Zainal, M., \& Hamzah, S. R.. International Journal of Academic Research in Business and Social Sciences, 7, $14: 77-85$ (2018)

12. Baharom, F. H. \& M. S. Pertanian dan komuniti luar bandar. Penerbit University Malaysia Sabah, 26 (2018)

13. Stuftlebeam, D.L., The CIPP Model for Program Evaluation. Dalam G.E. Madaus, M. Scriven \& D.L. Stufflebeam (ms. 117-141). Evaluation Models: Viewpoints on Educational and Human Services Evaluation. Boston: Kluwer- Nijhoff Publishing (1983)

14. Stufflebeam, D.L. The CIPP model for evaluation. In Stufflebeam, D.L., Madaus, G.F. Kellaghan, T. (Eds). Evaluation Models. Viewpoints on Educational and Human Service Evaluation. (pp. 279-317). 2nd edition. Boston: Kluwer Academic (2000a)

15. Tuan Mohd Yasin, S. N. H. Kerangka Penambahbaikan Pelaksanaan Program Diploma Kejuruteraan Mekatronik Politeknik (2017)

16. Gurning, R. N. S., Mulyo, J. H. M., \& Masyhuri, . Performance of Agribusiness Microfinance Institutions (MFIA) by using Context, Input, Process, and Product (CIPP) in Gunungkidul, Yogyakarta, Indonesia. Archives of Agriculture and Environmental Science, 4(2), 190-197, (2019).

17. Man, N. Economic and Technology Management Review, 5, 57-69 (2010)

18. DeHegedus, O. P. An evaluation of agricultural development projects recently conducted in Uruguay: guidelines for an extension (1994).

19. Van den Ben, A. W. Extension policies, policy types, policy formulation, and goals. In Gwyn E. Jones (ed.). Investing in rural extension: Strategies and goals (pp. 91-97). London: Elsevier Applied Science Publishers (1986)

20. Csaki, C., \& Lerman, Z. Structural change in the farming sectors in Central and Eastern Europe: lessons for the EU accession. Washington, D.C.: World Bank (2000)

21. Azizi-khalkheili, T., Sciences, S. A., \& Bijani, M. Programs The Case of Sheep Breeders in Pasargad. December, (2017)

22. Suvedi, B. M., \& Stoep, G. Vander. Improving the Monitoring and Evaluation of Agricultural Extension Programs. July (2016)

23. Evenson, R. E., \& Jaha, D. The contribution of the agricultural research system to agricultural production in India. Indian Journal of Agricultural Economics, 28(4), 212230 (1973).

24. Bradfield, D.J. Guide to extension training. FAO, Rome (1996)

25. Chambers, R. Whose reality- counts? Putting the first last. London: Intermediate Technology Publications (1997) 